\title{
Prickly Pear Cactus Responses to Summer and Winter Fires
}

\author{
R. James Ansley ${ }^{1}$ and Michael J. Castellano ${ }^{2}$ \\ Authors are ${ }^{1}$ Professor and ${ }^{2}$ Research Associate, Texas Agricultural Experiment Station, PO Box 1658, Vernon, TX 76384.
}

\begin{abstract}
Prescribed fire is used to reduce size and density of prickly pear cactus (Opuntia spp.) in many rangeland ecosystems. However, effects of dormant season fires (i.e., winter fires) are inconsistent. Thus, there is increasing interest in use of growing season (summer) fires. Our objective was to evaluate effects of fire season and fire intensity on mortality and individual plant (i.e., "motte") structure (area per motte, cladodes per motte, motte height) of brownspine prickly pear (O. phaeacantha Engelm.). The study had 4 treatments: no fire, low-intensity winter fire, high-intensity winter fire, and summer fire. Three sizes of prickly pear mottes were evaluated: small (0-20 cladodes per motte), medium (21-100), and large (101-500). At 3 years postfire, prickly pear mortality in the summer fire treatment was $100 \%$ in small mottes, $90 \%$ in medium mottes, and $80 \%$ in large mottes. Motte mortality increased in this treatment over time, especially in large mottes. Mortality from high-intensity winter fires was $29 \%$ and $19 \%$ in small and medium mottes, respectively, but no large mottes were killed. Motte mortality was $<10 \%$ in low-intensity winter fire and no-fire treatments. Summer fires reduced all motte structural variables to 0 in small mottes and nearly 0 in other motte size classes. High-intensity winter fires reduced some structural variables of medium and large mottes, but had no long-term negative effects on area per motte or cladodes per motte in surviving small mottes. Low-intensity winter fires had no long-term negative effects on motte structure in any size class. Rapid growth of mottes, and especially small mottes, in the no-fire treatment suggested that resistance to winter fires can occur rapidly.
\end{abstract}

\section{Resumen}

En muchos ecosistemas de pastizal, el fuego prescrito es utilizado para reducir el tamaño y densidad de nopal (Opuntia spp.). Sin embargo, los efectos del fuego que ocurre en época de dormancia (fuegos en invierno) son inconsistentes. Hay un creciente interés en usar fuego en la estación de crecimiento, es decir fuegos en verano. Nuestro objetivo fue evaluar los efectos de la época de quema en la mortalidad y estructura de las plantas individuales ('motte') (área, número de cladodios y altura del 'motte') del "Brownspine prickly pear" (O. phaeacantha Engelm.). El estudio tuvo cuatro tratamientos: sin quema (control), fuego de baja intensidad en invierno, fuego de alta intensidad en invierno y fuego en verano. Se evaluaron tres tamaños de 'motte', pequeños (0-20 cladodios por 'motte'), medianos (21-100) y grandes (101-500). Tres años después de aplicar el fuego, la mortalidad del “Brownspine prickly pear" en el tratamiento de fuego en verano ascendió a $100 \%$ en los 'mottes' pequeños, $90 \%$ en los medianos y $80 \%$ en los grandes. En este tratamiento, la mortalidad aumentó a través del tiempo, especialmente en los 'mottes grandes'. La mortalidad con el fuego de alta intensidad en invierno fue $29 \%$ y $19 \%$ en los 'mottes' pequeños y medianos, respectivamente y ninguno de los 'mottes' grandes murió. La mortalidad de 'mottes' fue $<10 \%$ en los tratamientos de fuego de baja intensidad de invierno y sin fuego. El fuego de verano redujo a cero todas las variables estructurales de los 'mottes' pequeños y a casi cero el los otros tamaños de 'motte'. Los fuegos de alta intensidad en invierno redujeron algunas variables estructurales de los 'mottes' medianos y grandes, pero en los motes pequeños sobrevivientes no tuvieron efectos negativos a largo plazo sobre el área o el número de cladodios por 'motte'. El fuego de baja intensidad en invierno no tuvo efectos negativos a largo plazo en la estructura de ningún tamaño de 'motte'. El rápido crecimiento de los 'mottes', especialmente los pequeños, en el tratamiento in fuego, sugiere que la resistencia al fuego en invierno ocurre rápidamente.

Key Words: brush management, fire behavior, prescribed fire, rangeland restoration, seasonal fires, woody plant encroachment

\section{INTRODUCTION}

Many grassland and savanna ecosystems worldwide have been encroached by woody plants and cacti in the last century (Freeman 1992; Van Auken 2000; Archer et al. 2001). One mechanism responsible for encroachment may be the in-

The study was funded in part by US Dept of Agriculture-National Research Initiative grant 94 04256, the Texas Agricultural Experiment Station (H-8310) and by the E. Paul and Helen Buck Waggoner Foundation, Vernon, Texas.

Correspondence: R. J. Ansley, Texas Agricultural Experiment Station, PO Box 1658, Vernon, TX 76384. Email: r-ansley@tamu.edu

Manuscript received 2 April 2006; manuscript accepted 27 February 2007. terruption of naturally occurring fire return intervals that are sufficiently frequent to limit woody encroachment (Collins and Wallace 1990; Van Auken 2000; Foxcroft et al. 2004; Briggs et al. 2005).

Prescribed fire is used to restore historical fire regimes in many grassland and savanna ecosystems and suppress woody plant encroachment (Wright and Bailey 1982; Scifres and Hamilton 1993). In the southern Great Plains of the United States, most prescribed fires have been conducted during the dormant season (January-March; winter fires). However, there has been increasing interest in the use of growing-season, or summer, fires because they may have a greater ability to suppress noxious woody plants and cacti (Ansley and Jacoby 
1998; Ansley and Taylor 2004). One justification for the use of summer fires is that, prior to European settlement, many if not most Great Plains fires occurred in summer because of the greater frequency of lightning strikes during summer than during winter (Frost 1998).

The use of prescribed fires to suppress noxious vegetation encroachment has focused on woody species such as honey mesquite (Prosopis glandulosa Torr.) and velvet mesquite (Prosopis velutina Woot.) and a variety of juniper (Juniperus spp.) species. However, in addition to woody plant encroachment, many grassland areas worldwide have become infested with several species of prickly pear cactus (Opuntia spp.). Although prickly pear is valued for food or wildlife habitat in many regions (Russell and Felker 1987; Thomas and Goodson 1992; Hernandez et al. 2003; Singh 2003; Kaufmann 2004), in other regions it is viewed as a noxious species that can reduce herbaceous production, increase soil erosion, and harm livestock (Reynolds and Bohning 1956; Bunting et al. 1980; Price et al. 1985; Freeman 1992; Vila et al. 2003; Foxcroft et al. 2004).

Prescribed fire is a viable management option for reducing prickly pear infestations in the southern Great Plains (Wright and Bailey 1982). However, anecdotal evidence from resource managers in this region suggests that winter fires are not as effective as summer fires in reducing prickly pear cover or density (Ansley and Taylor 2004). This is especially true in central Texas where cool-season $\mathrm{C}_{3}$ grasses are often green during winter and retard intensity of winter fires (Ansley and Jacoby 1998).

Prickly pear resistance to fire may depend on the physiognomic structure of prickly pear plants or "mottes" (Heirman and Wright 1973; Bunting et al. 1980). The term "motte" is defined here as an individual plant that consists of a discernable cohort of connected ramets and cladodes with a clear land-area gap between other cohorts. As motte size increases, the herbaceous vegetation that ordinarily fuels fire becomes almost nonexistent in the central portion of the motte, allowing centers of large mottes to avoid fire (Scifres and Hamilton 1993). In addition, the flat, oval-shaped cladodes located on the outer portions of the motte may physically shield more centrally located cladodes from fire effects. Thus, as motte canopies expand laterally through growth of more cladodes, this shielding effect may be expected to increase, although to our knowledge, this has not been documented. Because of their greater intensity, summer fires may have greater potential than winter fires in directing more heat toward the centers of these larger mottes and thus killing the entire motte (Thomas 1991; Ansley and Taylor 2004). However, we know of no work that has quantified the relation between motte size and responses to seasonal fires or same-season fires of different intensities.

Our objectives were to 1) determine the effect of seasonal fires on mortality and motte physiognomic structure of brownspine prickly pear cactus (Opuntia phaeacantha Engelm.) and 2) determine how mottes of different sizes respond to seasonal fires. We hypothesized that 1 ) summer fires $>$ highintensity winter fires $>$ low-intensity winter fires in increasing motte mortality and 2) summer fires $>$ high-intensity winter fires $>$ low-intensity winter fires in decreasing motte structure. With respect to motte size, we hypothesized that 3) within a particular fire treatment, resistance to fire would increase with increasing motte size.

\section{METHODS}

\section{Site Description}

Research was conducted on a private ranch $18 \mathrm{~km}$ south of Electra in north-central Texas (lat $33^{\circ} 53^{\prime} 30^{\prime \prime} \mathrm{N}$; long $\left.99^{\circ} 03^{\prime} 30^{\prime \prime} \mathrm{W}\right)$. Mean annual rainfall was $665 \mathrm{~mm}$ with peak rainfall months in May $(119 \mathrm{~mm})$ and September $(77 \mathrm{~mm})$. Mean monthly air temperatures ranged from a maximum of $36^{\circ} \mathrm{C}$ in July to a minimum of $-2.5^{\circ} \mathrm{C}$ in January. Soils were fine, mixed, thermic Typic Paleustolls of the Tillman series that were alluvial clay loams to 3-4 m depth, underlain by sandstone and shale parent material (Koos et al. 1962).

The prefire overstory initially consisted of honey mesquite (3-4-m-tall trees, 20\%-30\% aerial cover) and brownspine prickly pear cactus $(10 \%-20 \%$ cover $)$. The herbaceous layer consisted of a mixture of $\mathrm{C}_{3}$ and $\mathrm{C}_{4}$ perennial grasses including $\mathrm{C}_{3}$ Texas wintergrass (Nasella leucotricha [Trin. and Rupr.] Pohl.), and $\mathrm{C}_{4}$ grasses buffalograss (Buchloe dactyloides [Nutt.] Engelm.), sideoats grama (Bouteloua curtipendula [Michx.] Torr.), and meadow dropseed (Sporobolus compositus [Poir.] Merr.). Nomenclature follows Diggs et al. (1999) except where noted. Growing season for $\mathrm{C}_{4}$ grasses is from April through October. Peak growth for $\mathrm{C}_{3}$ grasses is March through May, but growth can occur throughout the year (Ansley et al. 2004). The area had not burned for at least 30 years prior to this study. Livestock grazing was excluded from the site during the study to allow herbaceous vegetation to accumulate and serve as fine fuel for fire, and to prevent postfire trampling of firedamaged mottes prior to evaluation.

\section{Treatments}

The study had 4 treatments: 1) no fire, 2) low-intensity winter fire, 3) high-intensity winter fire, and 4) summer fire, with 3 randomly arranged replicate plots per treatment. Each replicate plot was 0.5 ha. Summer fires were applied in September 1997. High-intensity winter fires were applied in late January or early February 1998. Low-intensity winter fires were applied in early March 1998 when the percentage of green tissue in the herbaceous layer (from $\mathrm{C}_{3}$ grass growth) was greater than in February and would retard fire intensity, but air temperatures at ignition remained similar to the earlier winter fires. Plots were separated by a 4-m-wide dozer line and all fires were conducted as headfires. Prior to headfire ignition, a backfire was established on downwind plot edges. No data were collected within the backfire area.

Air temperature, relative humidity, and wind speed were measured on site $<10$ minutes prior to each fire. In each plot prior to burning, herbaceous fine fuel amount (litter + grass and forb standing crop) was estimated by harvesting 100.25 $\mathrm{m}^{2}$ quadrats located in interstitial spaces between mesquite trees and cactus mottes.

Flame length was estimated by videotaping the flame front as it passed 4 metered metal standards within each plot. Fire intensity was quantified using the flame-length data and the equation of Byram (1959):

$$
\mathrm{I}=5.7 \mathrm{~L}^{2.2}
$$

where $\mathrm{I}=$ fireline intensity $\left(\mathrm{BTU} \cdot \mathrm{feet}^{-1} \cdot \mathrm{s}^{-1}\right)$ and $\mathrm{L}=$ flame 
Table 1. Pretreatment motte structural characteristics of the 3 motte size classes of brownspine prickly pear identified in the study. Means are averaged over all replicate plots, including those later burned (standard error in parentheses; sample size $n$ shown for each size class).

\begin{tabular}{ccccc}
\hline Motte size class & Sample size & Cladodes per motte & Canopy area per motte & Height per motte \\
\hline & & No. & $\mathrm{m}^{2}$ & $\mathrm{~m}$ \\
Small & 91 & $9.2(0.5)$ & $0.19(0.02)$ & $0.28(0.01)$ \\
Medium & 80 & $41.6(1.8)$ & $1.26(0.08)$ & $0.39(0.01)$ \\
Large & 58 & $218.1(16.6)$ & $7.99(0.69)$ & $0.52(0.03)$ \\
\hline
\end{tabular}

length (feet). Intensity values were converted from BTU • feet $^{-1} \cdot \mathrm{s}^{-1}$ to $\mathrm{kW} \cdot \mathrm{m}^{-1}$.

\section{Prickly Pear Measurements}

Prickly pear responses were measured 1 month prior to each fire treatment, and at 2 months, 1 year, and 3 years after the winter fire treatments. The summer fire treatment occurred 5 months prior to the winter fire treatments, but, for purposes of clarity, postfire durations were portrayed on the same time scale as the winter fire treatments.

Prior to burning, individual prickly pear mottes that were spatially separated from other mottes were tagged within each plot. Three motte size classes were identified, based on number of mature cladodes per motte. A cladode was considered mature if both length and width exceeded $10 \mathrm{~cm}$. Motte size classes were small (2-20 cladodes $\cdot$ motte $\left.^{-1}\right)$, medium (21-100 cladodes $\cdot$ motte $\left.^{-1}\right)$, and large $\left(101-500\right.$ cladodes $\cdot$ motte $\left.^{-1}\right)$. Each increasing size class was designed to be $4-5$ times greater, with respect to cladode number, than the previous size. Cladode counts were done by 3-4 observers per motte and then these counts were averaged. Canopy area (CA) per motte was determined by the following equation:

$$
\mathrm{CA}=\pi a b
$$

where $a=$ length of the longest lateral extension of the motte and $b=$ length of the widest part of each motte that was perpendicular to $a$. Motte height was determined to the nearest $0.1 \mathrm{~m}$ by measuring distance from ground to the top of the highest cladode within each motte. Average pretreatment cladode number per motte, area per motte and motte height for each size class are shown in Table 1. Five to 9 mottes were evaluated per size class in each plot, and a total of 229 mottes were evaluated.

Postfire measurements included percentage of motte mortality, and area per motte, cladodes per motte, and motte height of surviving mottes. A motte was counted as dead if there was no evidence of aboveground green tissue. Motte structure variables were measured as previously described. If live portions of a large motte became fragmented from fire, then canopy area and cladode number of each fragment were quantified and summed as the value for that motte. The top of the highest cladode in any of the fragments was used as the measure of height.

Percentage of change of area per motte, cladodes per motte and motte height from pretreatment amount to each posttreatment date was determined by the following equation:

$$
\% \text { Change }=\left(\frac{\text { Pre }- \text { Post }}{\text { Pre }}\right) \times(100) \times(-1)
$$

where Pre $=$ pretreatment value, and Post $=$ posttreatment value at 2 months, 1 year, or 3 years posttreatment. All percent-change values were presented in relation to the pretreatment value and do not represent the change from one posttreatment date to another.

\section{Analyses}

Treatment effects on the dependent variables of percentage of motte mortality, canopy area per motte, cladodes per motte, and motte height were analyzed within each motte size class using a repeated measures general linear model, with fire treatment and time postfire as main effects (SPSS 2003). Oneway analyses of treatment effects were conducted within each sample date if significant treatment-by-time interactions occurred. Absolute values for these variables as well as percentage of change relative to pretreatment values were analyzed. Mean separation was performed with LSD $(P<0.05)$. Mortality percentage data were transformed prior to analysis using arcsin transformation. Nonnormal data were square-root transformed prior to analysis (Zar 1999).

The pretreatment relationship between area per motte and cladodes per motte or motte height was determined through curvilinear regressions with canopy area per motte as the independent variable. These relationships did not directly relate to stated hypotheses but provided greater understanding of the prefire physiognomic structure of this species.

\section{RESULTS}

\section{Fire Behavior and Precipitation}

Summer fires were most intense followed by high-intensity winter fires, then low-intensity winter fires (Table 2). Over $90 \%$ of the soil surface was blackened in summer and highintensity winter fires, whereas only $50 \%$ of the soil surface was blackened in the low-intensity winter fire treatment (R.J. Ansley, visual estimate, 1998).

Precipitation was slightly above normal in most months prior to summer 1997 or winter 1998 fires (Fig. 1). During the postfire data collection period from March 1998 to April 2001, precipitation was below the 30-year average in 11 of the 19 bimonthly periods. Thus, the overall trend was drier than normal with severe droughts during the 1998 growing season and the last half of 1999 .

\section{Pretreatment Cladode and Canopy Relations}

Prior to fire treatments, there was a significant quadratic relationship between motte canopy area and number of cladodes per motte (Fig. 2). The relationship between motte area and motte height loosely $\left(r^{2}=0.53\right)$ fit a power curve that 
Table 2. Weather variables, herbaceous fine fuel, and fire intensity within each fire treatment. High winter = high-intensity winter fire; Low winter $=$ low-intensity winter fire. All values are means of 3 plots (standard error in parentheses).

\begin{tabular}{cccccccc}
\hline Fire treatment $^{1}$ & Air temperature & Relative humidity & Wind speed & Herbaceous fine fuel & Flame height & Flame length & Fire intensity \\
\hline & ${ }^{\circ} \mathrm{C}$ & $\%$ & $\mathrm{~m} \mathrm{~s}^{-1}$ & $\mathrm{~g} \mathrm{~m}^{-2}$ & $\mathrm{~m}$ & $\mathrm{~m}$ & $\left(\mathrm{~kW} \mathrm{~m}{ }^{-1}\right)$ \\
Summer & $31.7(1.4)$ & $36.3(6.2)$ & $1.5(0.7)$ & $369(17)$ & $2.7(0.2)$ & $4.5(0.3)$ & $7446(1041)$ \\
High winter & $21.9(0.5)$ & $23.7(3.2)$ & $5.2(0.3)$ & $252(21)$ & $2.2(0.4)$ & $3.5(0.3)$ & $4314(770)$ \\
Low winter & $23.3(2.5)$ & $28.3(2.5)$ & $2.2(0.4)$ & $248(4)$ & $0.9(0.2)$ & $1.6(0.3)$ & $791(282)$ \\
\hline
\end{tabular}

${ }^{1}$ Winter fire (January-March); summer fire (September).

reached a plateau after motte area exceeded $5 \mathrm{~m}^{2}$. Motte height never exceeded $0.8 \mathrm{~m}$ even though canopy area of the largest motte was nearly $25 \mathrm{~m}^{2}$.

\section{Motte Mortality}

Within the summer fire treatment, motte mortality increased in all 3 size classes over time and, by 3 years postfire, was 100\% in small, $90 \%$ in medium, and $80 \%$ in large mottes (Fig. 3A). Mortality from summer fires increased in large mottes from $17 \%$ to $43 \%$ to $80 \%$ at 2 months, 1 year, and 3 years postfire, respectively. Motte mortality in the high-intensity winter fire treatment was not nearly as great as in the summer fire treatment in any size class (Fig. 3B). Mortality in small and medium-sized mottes increased slightly to $29 \%$ and $19 \%$, respectively, by 3 years postfire in this treatment. Motte mortality remained $<10 \%$ in small mottes and $<5 \%$ in medium mottes in the low-intensity winter fire and no-fire

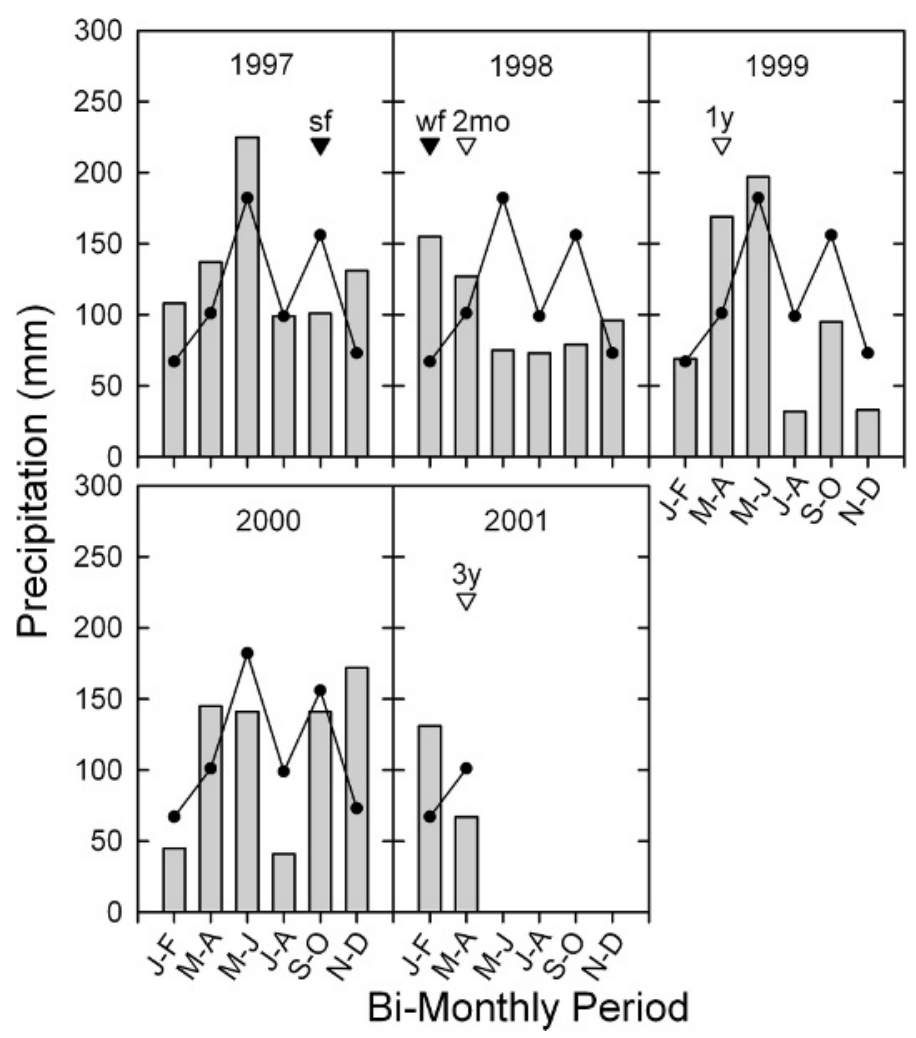

Figure 1. Bimonthly precipitation at the study site (bars) compared to 30-year average (line) during the study period. Black triangles indicate dates of summer fire (sf) and winter fire (wf) treatments. Open triangles indicate data collection periods at 2 months (2 mo), 1 year (1 y) and 3 years $(3 \mathrm{y})$ after the winter fire treatment. treatments throughout the study (data not shown). No mortality of large mottes occurred in either winter fire treatment or the no-fire treatment.

\section{Motte Structural Responses}

Prefire measurements indicated that prickly pear canopy area per motte, cladodes per motte, and height per motte were similar across all treatments within each motte size class (Figs. 4-6). Analysis indicated significant treatment-by-time interactions for all 3 structural variables.

Summer fires reduced area per motte to 0 in small mottes and nearly 0 in medium and large mottes (Fig. 4). High-intensity
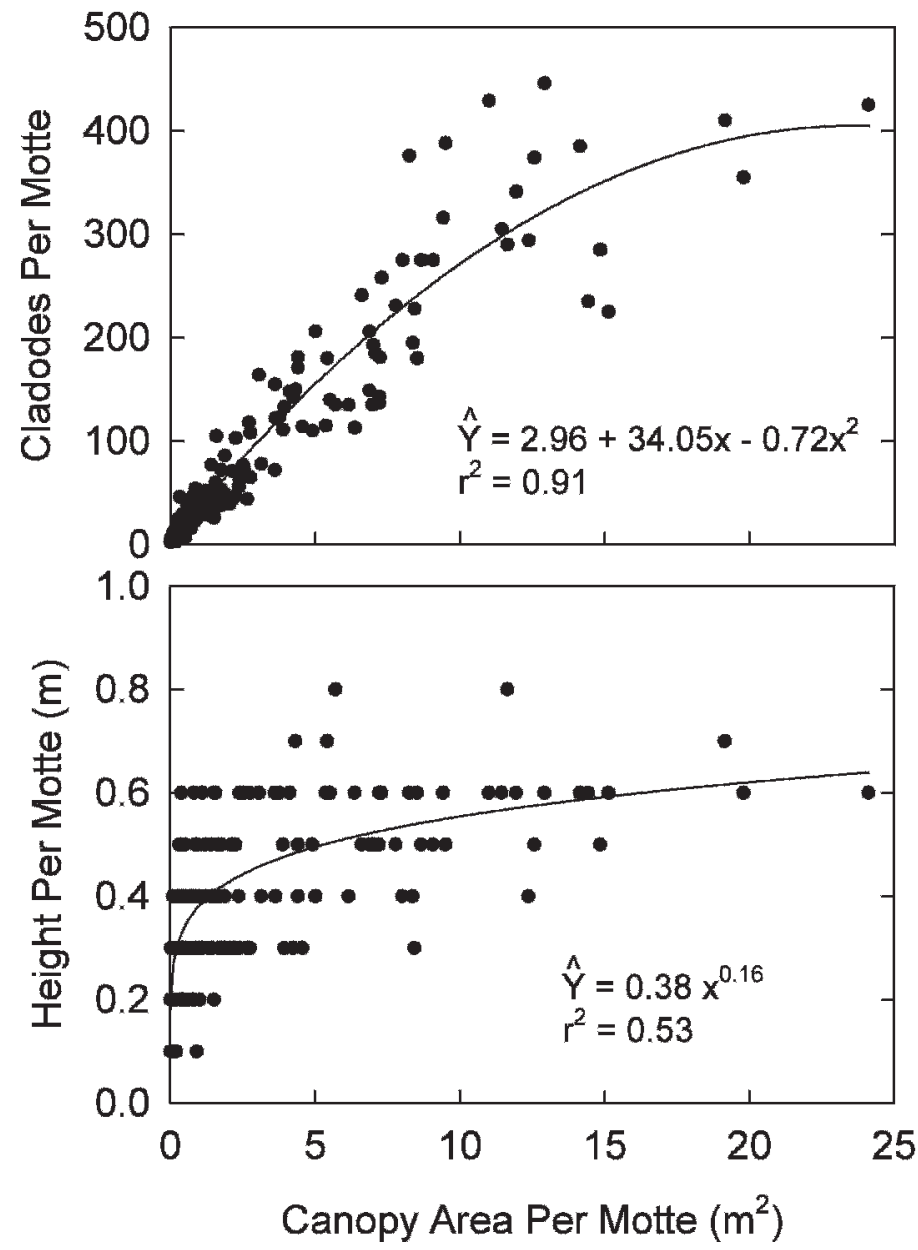

Figure 2. Pretreatment relationship between prickly pear canopy area per motte and cladodes per motte (top) or height per motte (bottom). Each point represents an individual motte and all mottes in the study are included $(n=229)$. 


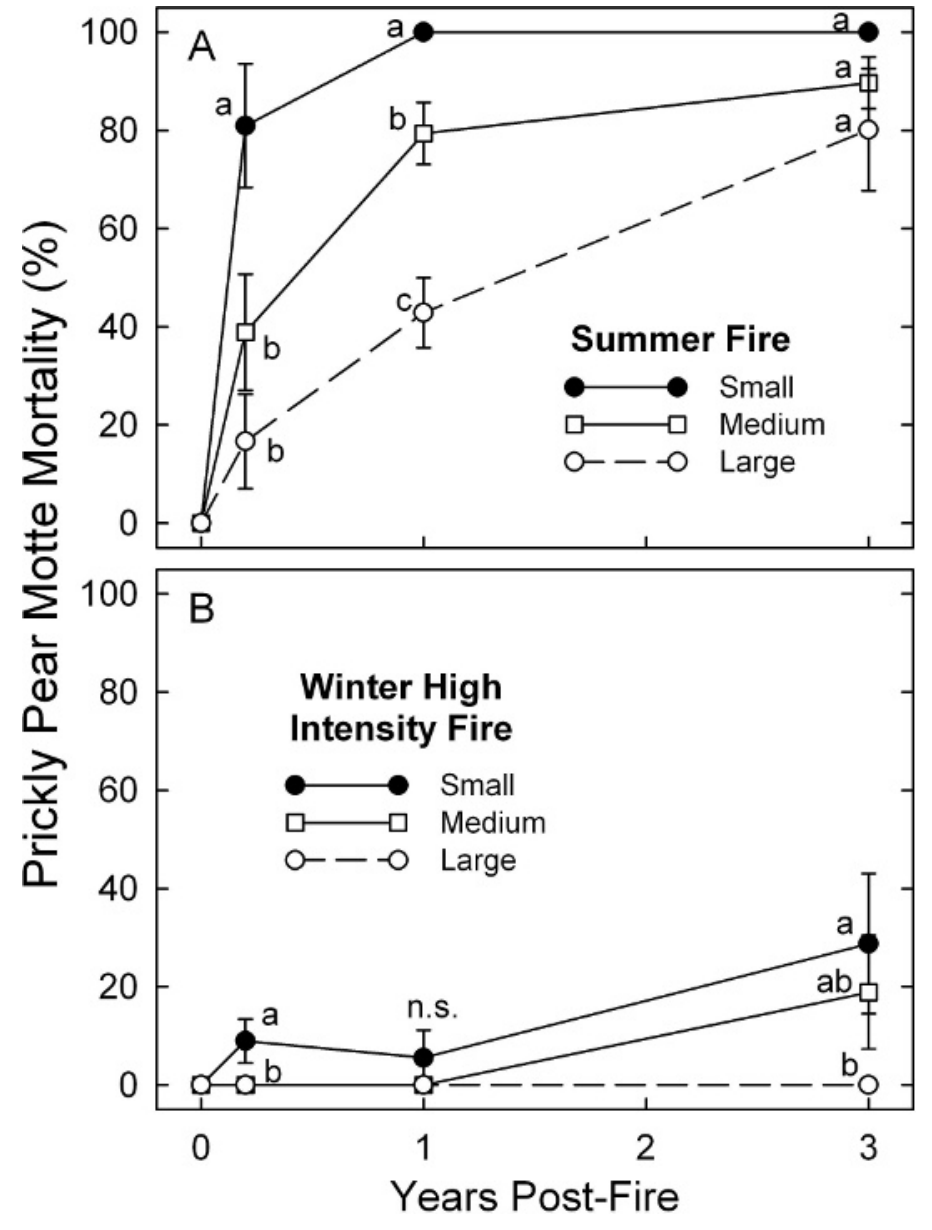

Figure 3. Prickly pear percent mortality in 3 motte size classes (small, medium, large) as affected by $\mathbf{A}$, summer fire and $\mathbf{B}$, high-intensity winter fire treatments and years postfire. Means within a sample date with similar letters are not significantly different $(P \leq 0.05)$. Vertical bars are \pm 1 standard error $(n=3)$.

winter fires initially reduced area per motte of small mottes, but, by 3 years postfire, area per motte of small mottes was much greater in this treatment than it was prior to treatment. High-intensity winter fires reduced area per motte of large mottes. In contrast, low-intensity winter fires had no lasting effect on reducing area per motte in any motte size class. The number of cladodes per motte followed a similar pattern of response to fire treatments as did area per motte, with the exception that, in small mottes, high-intensity winter fires were more effective at limiting long-term increases in cladodes per motte than in limiting gains in area per motte (Fig. 5).

Summer fires decreased motte height to 0 in small mottes and near 0 in medium and large mottes by 3 years postfire (Fig. 6). Similar to the mortality data, height of large mottes progressively declined over time in the summer fire treatment. High-intensity winter fires decreased motte height by about $50 \%$ in all size classes, but low-intensity fires had virtually no long-term effect on reducing motte height.

\section{Percentage of Change in Structural Responses}

Over the 3-year study period, motte canopy area in the no-fire treatment increased by $353 \%, 105 \%$, and $7 \%$ in small,
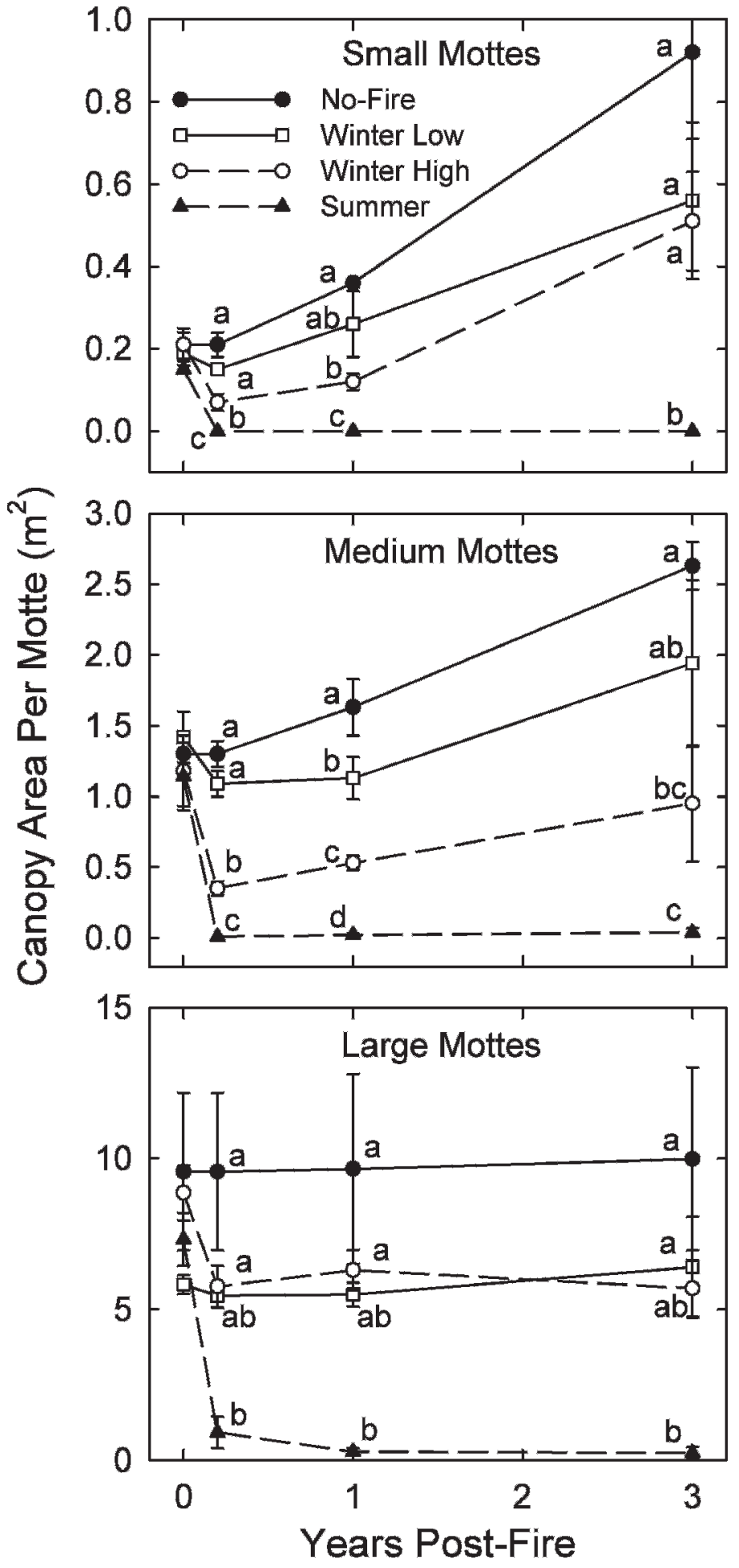

Figure 4. Canopy area per motte in 3 motte size classes as affected by fire treatments at different postfire dates. Winter Low $=$ low-intensity winter fire, Winter High $=$ high-intensity winter fire, and Summer $=$ summer fire. Means within a sample date with similar letters are not significantly different $(P \leq 0.05)$. Vertical bars are \pm 1 standard error $(n=3)$.

medium, and large mottes, respectively (Table 3). The same trend was found with cladodes per motte, although differences between size classes were not as great $(135 \%, 76 \%$, and $46 \%$ increase in small, medium, and large mottes, respectively). In 


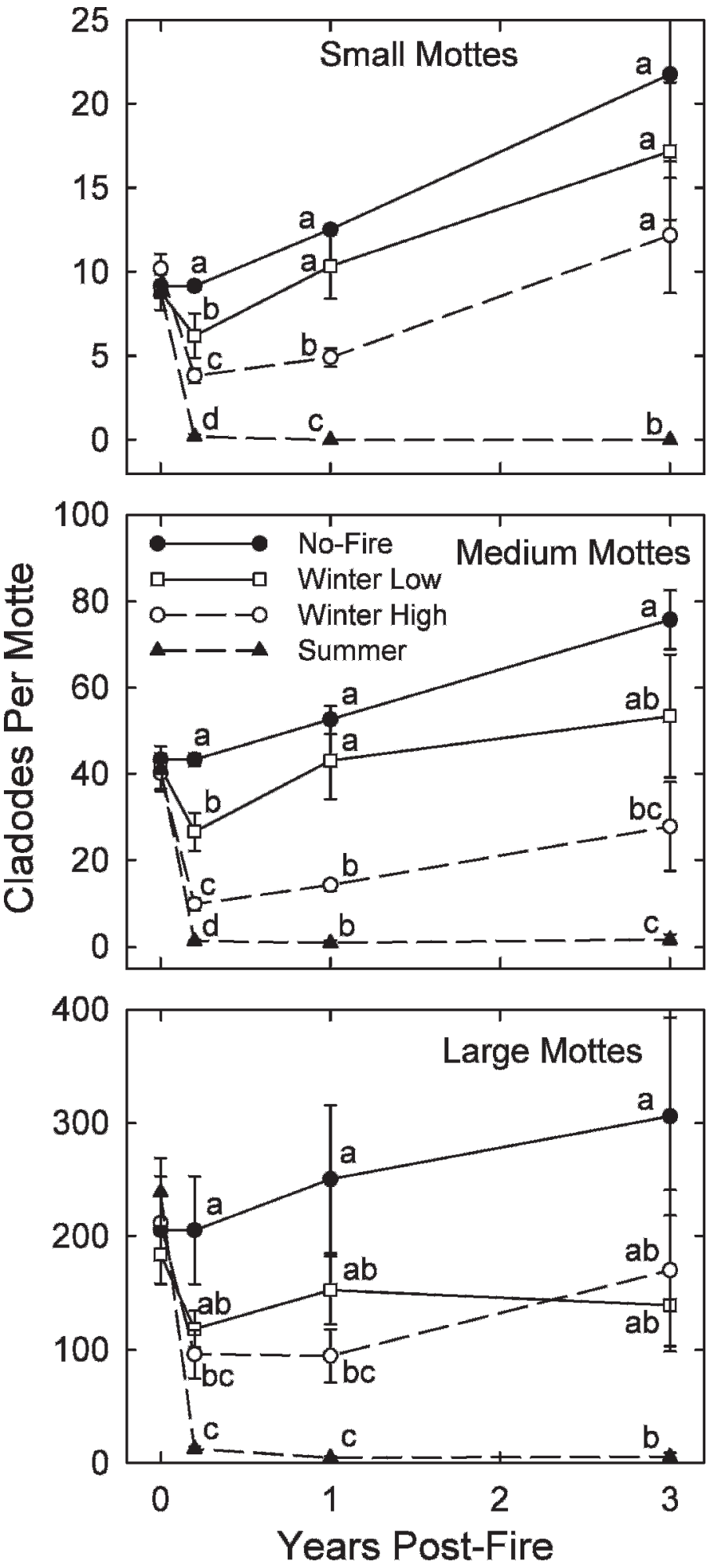

Figure 5. Number of cladodes per motte in 3 motte size classes as affected by fire treatments at different postfire dates. Treatment and mean separation details are the same as for Figure 4.

contrast, motte height in the no-fire treatment decreased in all size classes; the decrease was greatest in small mottes $(-32 \%$, $-24 \%$, and $-17 \%$ in small, medium, and large mottes, respectively).
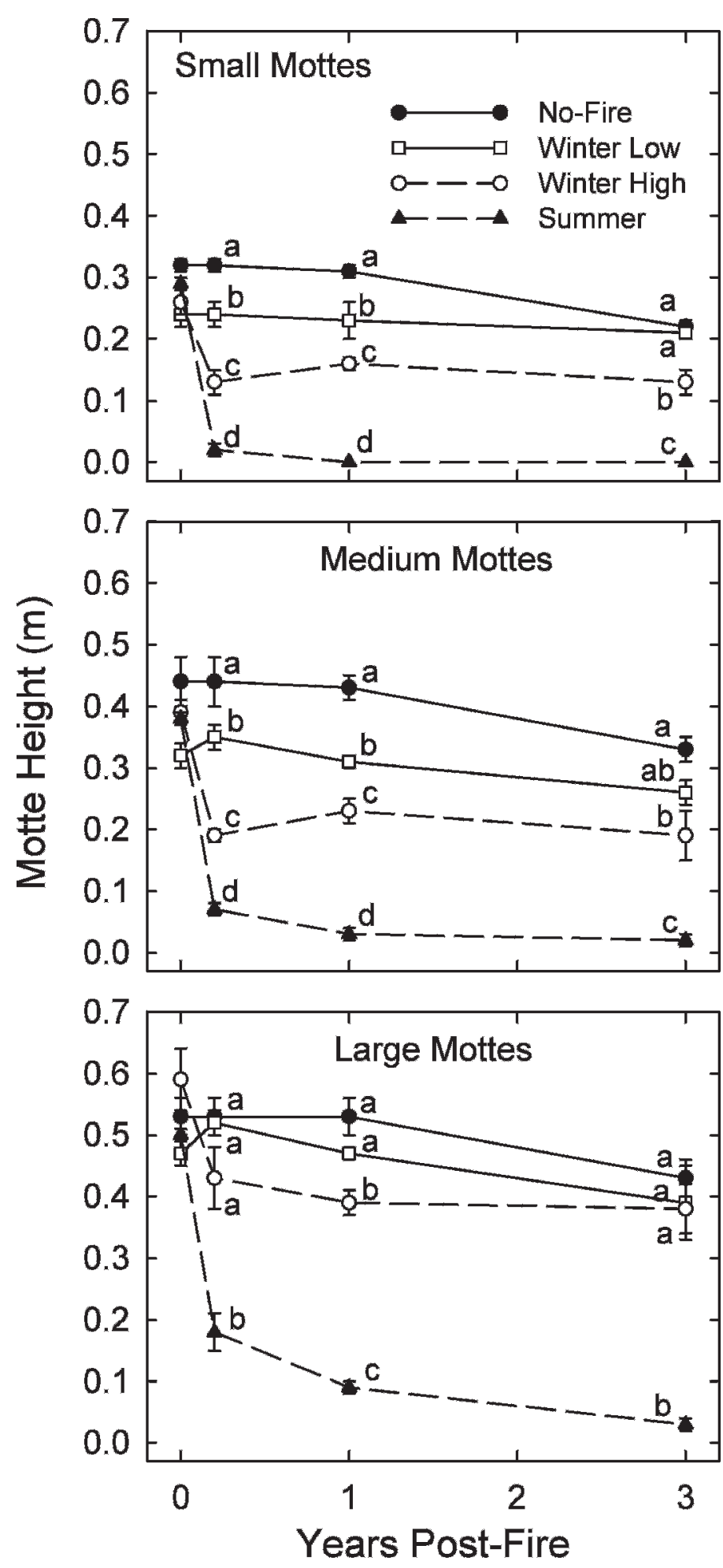

Figure 6. Motte height in 3 motte size classes as affected by fire treatments at different postfire dates. Treatment and mean separation details are the same as for Figure 4.

Among fire treatments, summer fires yielded a large negative percent change $(-100 \%$ in small mottes and $-95 \%$ to $-98 \%$ in medium and large mottes) in all 3 structural categories (area per motte, cladode number, and height). Yields from high-intensity winter fires were mostly negative (range $-7 \%$ to $-52 \%$ ), with the exception that area per motte and cladodes per motte of 
Table 3. Three-year posttreatment change (\%) relative to pretreatment prickly pear structural values calculated from Figures 4-6. High winter $=$ high-intensity winter fire; Low winter = low-intensity winter fire. Values are means of 3 plots (standard error in parentheses). Similar letters within each size class and response variable indicates no significant difference $(P<0.05)$.

\begin{tabular}{|c|c|c|c|c|}
\hline Size class & Treatment $^{1}$ & Area per motte & Cladodes per motte & Height per motte \\
\hline & & $\%$ & $\%$ & $\%$ \\
\hline \multirow[t]{4}{*}{ Small } & No-fire & 352.5 (82.6) a & $135.3(49.3) \mathrm{a}$ & $-32.2(0.07) a b$ \\
\hline & Low winter & $181.6(81.5) \mathrm{a}$ & $100.0(48.8) \mathrm{a}$ & $-12.0(6.6) \mathrm{a}$ \\
\hline & High winter & $154.6(82.9) \mathrm{a}$ & $26.3(40.9) a b$ & $-48.7(10.5) b$ \\
\hline & Summer & $-100.0(0) b$ & $-100.0(0) b$ & $-100.0(0) c$ \\
\hline \multirow[t]{4}{*}{ Medium } & No-fire & $104.6(20.2) \mathrm{a}$ & $76.3(22.1) \mathrm{a}$ & $-23.9(9.9) \mathrm{a}$ \\
\hline & Low winter & $32.6(32.3) a b$ & 24.3 (19.5) ab & $-19.8(6.7) \mathrm{a}$ \\
\hline & High winter & $-7.2(39.9) b c$ & $-28.1(26.3) b$ & $-52.4(8.6) b$ \\
\hline & Summer & $-94.8(4.3) \mathrm{C}$ & $-95.3(2.8) \mathrm{C}$ & $-94.9(3.2) \mathrm{C}$ \\
\hline \multirow[t]{4}{*}{ Large } & No-fire & $6.6(13.9) \mathrm{a}$ & 46.3 (14.7) a & $-17.0(9.1) \mathrm{a}$ \\
\hline & Low winter & $8.0(23.1) \mathrm{a}$ & $-26.7(8.7) a b$ & $-17.3(8.7) \mathrm{a}$ \\
\hline & High winter & $-36.4(6.5) \mathrm{a}$ & $-20.6(32.3) b$ & $-33.8(10.9) \mathrm{a}$ \\
\hline & Summer & $-96.8(2.4) b$ & $-97.9(1.5) \mathrm{c}$ & $-94.9(2.6) b$ \\
\hline
\end{tabular}

${ }^{1}$ Winter fire (January-March); summer fire (September).

small mottes increased by $155 \%$ and $26 \%$, respectively. Lowintensity fires yielded few negative values and none were significantly more negative than the no-fire treatment.

\section{DISCUSSION}

Based on the results we failed to reject hypothesis 1: summer fires $>$ high-intensity winter fires $>$ low-intensity winter fires in increasing motte mortality. We also fail to reject hypothesis 2: summer fires $>$ high-intensity winter fires $>$ low-intensity winter fires in decreasing motte size. Summer fires clearly reduced area per motte, cladodes per motte, and motte height to a greater degree than the other treatments. In addition, highintensity winter fires reduced area per motte and motte height more than did low-intensity winter fire treatments. With respect to hypothesis 3, we found that motte size increased mortality resistance to the high-intensity winter fire treatment. However, because a large percentage of mottes in all size classes were killed by summer fires, we reject hypothesis 3, which stated that within in a particular fire treatment, resistance to fire would increase with increasing motte size.

The summer fire treatment in our study yielded greater prickly pear mortality than that found in other studies, with the exception of McLaughlin and Bowers (1982) who found that a summer (June) wildfire in the Sonoran desert of Arizona killed nearly $100 \%$ of O. phaeacantha. Cable (1967) found in Arizona that summer fires caused $32 \%$ and $23 \%$ mortalities of Opuntia engelmannii Salm-Dyck, a species closely related to $O$. phaeacantha, on 2 different sites. Reynolds and Bohning (1956) found in Arizona that a summer fire yielded only $28 \% \mathrm{O}$. engelmannii mortality and attributed the low mortality to high moisture content in the cladodes. Humphrey and Everson (1951) found only 9\% O. engelmannii mortality following a summer fire in Arizona. Differences may relate to a more consistent herbaceous fine fuel supply in our study.

The winter fire treatments in our study did not negatively affect prickly pear as much as found in other studies; greatest mortality was $29 \%$ in the small size class. Heirman and Wright
(1973) found that late-winter (March) fires killed $68 \%$ of $O$. phaeacantha in west Texas. Bunting et al. (1980) found an average of $60 \%$ O. phaeacantha mortality from several west Texas fires, although responses from late-winter prescribed fires and a summer wildfire were combined. The intensity of the high-intensity winter fire treatment in our study was not as high as has been reported for some other winter fires in this fuel type (Ansley and Jacoby 1998), but was typical for winter fires in this region.

None of the previous studies mentioned directly contrasted effects of summer and winter fires, as in the present study. We found that summer fires were clearly superior to winter fires of either intensity with respect to increasing mortality, and reducing motte canopy structure. Similar to our results, Taylor (2001), in the Edwards Plateau of south central Texas, found that summer fires were more effective than winter fires at reducing prickly pear (Opuntia sp.) density (97\% vs. $47 \%$ ).

\section{Mechanisms of Response to Fire}

Physiologically active plants are theorized to be more negatively affected by fire than are physiologically dormant plants (Daubenmire 1968; Trollope 1984). Thus, it is possible that the greater prickly pear mortality caused by summer fires in our study was because of this physiological activity, but the mechanisms involved are poorly understood.

From a physical standpoint, differences in prickly pear responses to seasonal fires might be attributed to a greater ability of summer fires to direct heat toward the center of large mottes. Flame length and height were considerably greater in the summer fire than in winter fire treatments and it may simply have been this physical difference in flame size that caused the greater effect by summer fires (Wright and Bailey 1982).

The shielding effect of cladodes possibly played a role in resistance of larger mottes to high-intensity winter fires. No large mottes died during the 3-year study period following high-intensity winter fires, whereas small motte mortality in this treatment eventually reached $29 \%$. As to the threshold size needed to survive fire, our results suggest that motte size needed 
to be larger than the largest size evaluated (mean 218 cladodes $\cdot$ motte ${ }^{-1}$; canopy area $8 \mathrm{~m}^{2}$ ) to resist summer fires, but mottes this size were resistant, with respect to mortality, to winter fires. The ability to kill large mottes may be one of the greatest advantages of summer fires over winter fires.

The increase in mortality over time, as shown with medium and large mottes in the summer fire treatment, and to a lesser degree with small and medium mottes in the high-intensity winter fire treatment, has been observed in other studies. Heirman and Wright (1973) and Bunting et al. (1980) found that O. phaeacantha mortality increased with postfire time and attributed this response to postfire insect or rodent predation. Sickerman and Wangberg (1983) found that the cactus bug (Chelinidea vittiger Uhler) preferred fire-damaged prickly pear (Opuntia polycantha Haw.; Weniger 1988) host plants to undamaged hosts in west Texas. Cave and Patten (1984) speculated that a further decline in cactus following fire may be because of fire-damaged plants dying later from latent heat damage to epidermal and mesophyll tissue. Summer fires may have been more effective at removing the wax layer on cladodes that initially survived fire, but later died because the loss of the wax layer reduced resistance to summer desiccation.

One of the more interesting observations in this study was the response of small motte canopy area to high-intensity winter fires. Although this treatment appeared to cause a reduction of small motte canopy area to less than half the pretreatment level at 2 months postfire, canopy area increased in this treatment to over twice pretreatment levels by 3 years postfire (Fig. 4). Such a response suggests that high-intensity winter fires were not effective in controlling the long-term growth of very small mottes that were not initially killed by fire. In contrast, summer fires completely eliminated small mottes.

\section{Motte Growth in the Absence of Fire}

Pretreatment motte structure data indicated a strong relationship between area per motte and cladodes per motte (Fig. 2). This suggests that the lateral expansion of motte area in this species is accomplished in large part through new cladode production. However, we cannot explain the nonlinear relationship caused by a lower cladode number relative to canopy area in mottes exceeding $15 \mathrm{~m}^{2}$. In contrast, the relatively poor relationship between motte canopy area and motte height indicates that maximum height is established early in small (and, we presume, young) mottes and there is little further investment in adding to height as motte canopies expand laterally.

The greater percentage of increase in area per motte (353\%) relative to the increase in cladodes per motte $(135 \%)$ in small mottes in the no-fire treatment (Table 3 ) indicates that, in this size class, the addition of a very few cladodes can cause a large increase in area per motte. In contrast, area per motte of large mottes increased only $7 \%$ over the 3 years, whereas cladode number increased $46 \%$ (Table 3). This opposite pattern between area and cladode number occurred in large mottes because a substantial addition of cladodes was required to affect an increase in motte canopy area. Percentage of increase in area per motte and cladodes per motte in medium mottes were similar $(105 \%$ vs. $76 \%)$, reflecting the transition from small to large mottes.
The rapid growth pattern of small and medium mottes suggests that, in the absence of fire, the transition from small or medium mottes to large mottes may occur quickly. A 353\% increase in area per motte in small mottes in 3 years (from Table 3), suggests that it would take only 5 years for small mottes of $0.2-\mathrm{m}^{2}$ canopy area (as defined in Table 1) to reach the $1.3 \mathrm{~m}^{2}$ canopy area size of medium mottes. Continuing this extrapolation, if the increase in canopy area of medium mottes was $105 \%$ in 3 years (Table 3), then it would take 15 years for medium mottes of $1.3-\mathrm{m}^{2}$ canopy area to reach the $8-\mathrm{m}^{2}$ canopy area size of large mottes. Thus, within a 20 -year period, small mottes, as defined in this study, would likely have developed into large mottes. These changes will likely vary with soil type, level of grass competition, degree of livestock grazing, and weather patterns, but they illustrate how, in the absence of fire, this and similar species of Opuntia can become dominant on the landscape in a short period of time.

\section{MANAGEMENT IMPLICATIONS}

Summer fires were more effective than winter fires in increasing prickly pear motte mortality and reducing motte canopy structure. High-intensity winter fires were more effective than low-intensity winter fires in increasing mortality of small and medium-sized mottes, but winter fires of either intensity did not kill large mottes. Moreover, small mottes that survived highintensity winter fires recovered from any structural damage caused by fire. Because of the rapid increase in motte canopy area of small and medium-sized mottes in the no-fire treatment, this study reinforces the importance of fire application during the early stages of prickly pear infestation when mottes are relatively small, herbaceous fuel remains adequate, and some mortality can be expected from winter fires, although probably not as much as from summer fires. However, the study also shows clearly that a low-intensity winter fire has virtually no long-term effect on even the smallest mottes. Thus, if prickly pear control is the objective, burning under marginal conditions will likely not yield desired results. In addition, goals related to use of low-intensity fires for mesquite savanna development (Ansley and Jacoby 1998) may not be compatible with use of fire to reduce prickly pear infestation.

\section{ACKNOWLEDGMENTS}

The authors are grateful for the land provided by the W. T. Waggoner Estate, Vernon, Texas. We thank Betty Kramp, David Jones, Gerral Schulz, Tim Tunnell, and Julie Huddle for their assistance in sampling and treatment implementation.

\section{LITERATURE CITED}

Ansley, R. J., And P. W. Jacoby. 1998. Manipulation of fire intensity to achieve mesquite management goals in north Texas. In: T. L. Pruden and L. A. Brennan [EDS.]. Fire in ecosystem management: Shifting the paradigm from suppression to prescription. Tall Timbers Fire Ecology Conference No. 20. 7-10 May 1996; Tallahassee, FL: Tall Timbers Research Station. p 195-204.

Ansley, R. J., and C. A. Taylor. 2004. The future of fire as a tool for managing brush. In: W. T. Hamilton, A. McGinty, D. N. Ueckert, C. W. Hanselka, and 
M. R. Lee [Eds.]. Brush management—Past, present, future. College Station: Texas A\&M University Press. p 200-210.

Ansley, R. J., W. R. Teague, W. E. Pinchak, B. A. Kramp, and D. L. Jones. 2004. Longterm grass yields following chemical control of honey mesquite. Journal of Range Management 57:49-57.

Archer, S., T. W. Boutton, and K. A. Hibbard. 2001. Trees in grasslands: biogeochemical consequences to woody plant expansion. In: E.-D. Schulze, M. Heimann, S. Harrison, E. Holland, J. Lloyd, I. C. Prentice, and D. Schimel [EDS.]. Global biogeochemical cycles in the climate system. San Diego, CA: Academic Press. p 115-137.

Briggs, J. M., A. K. Knapp, J. M. Blair, J. L. Heisler, G. A. Hoch, M. S. Lett, and J. K. McCarron. 2005. An ecosystem in transition: causes and consequences of the conversion of mesic grassland to shrubland. BioScience 55:243-254.

Bunting, S. C., H. A. Wright, and L. F. Neuenschwander. 1980. Long-term effects of fire on cactus in the southern mixed prairie of Texas. Journal of Range Management 33:85-88.

Byram, G. M. 1959. Combustion of forest fuels. In: K. P. Davis [ED.]. Forest fire: Control and use. New York, NY: McGraw-Hill Book Co. p 61-89.

CABLE, D. R. 1967. Fire effects on semidesert grasses and shrubs. Journal of Range Management 20:170-176.

Cave, G. H., and D. T. Patten. 1984. Short-term vegetation responses to fire in the upper Sonoran desert. Journal of Range Management 37:491-496.

Collins, S. L., and L. L. Wallace. 1990. Fire in North American tallgrass prairie. Norman: University of Oklahoma Press. $175 \mathrm{p}$.

Daubenmire, R. 1968. Ecology of fire in grasslands. Advances in Ecological Research 5:207-266.

DigGs, G. M., B. L. Lipscomb, And R. J. O'Kennon. 1999. Illustrated flora of north central Texas. Fort Worth: Botanical Research Institute of Texas. 1626 p.

Foxcroft, L. C., M. Rouget, D. M. Richardson, and S. MacFadyen. 2004. Reconstructing 50 years of Opuntia stricta invasion in the Kruger National Park, South Africa: environmental determinants and propagule pressure. Diversity and Distributions 10:427-437.

Freeman, D. B. 1992. Prickly pear menace in eastern Australia 1880-1940. Geographical Review 82:413-429.

Frost, C. C. 1998. Presettlement fire frequency regimes of the United States: a first approximation. In: T. L. Pruden and L. A. Brennan [EDS.]. Fire in ecosystem management: Shifting the paradigm from suppression to prescription. Tall Timbers Fire Ecology Conference No. 20. 7-10 May 1996; Tallahassee, FL: Tall Timbers Research Station. p 70-81.

Heirman, A. L., And H. A. Wright. 1973. Fire in medium fuels of west Texas. Journal of Range Management 26:331-335.

Hernandez, F., S. E. Henke, N. J. Silvy, and D. Roluins. 2003. The use of prickly pear cactus as nesting cover by northern bobwhites. Journal of Wildlife Management 67:417-423.

Humphrey, R. R., and A. C. Everson. 1951. Effect of fire on a mixed grass-shrub range in southern Arizona. Journal of Range Management 4:264-266.
Kaufmann, J. C. 2004. Prickly pear cactus and pastoralism in southwest Madagascar. Ethnology 43:345-361.

Koos, W. M., J. C. Williams, And M. L. Dixon. 1962. Soil Survey at Wilbarger County, Texas. Soil Survey Series 1959 No. 18. Fort Worth, TX: USDA Soil Conservation Service. 64 p.

McLaughlin, S. P., AND J. E. Bowers. 1982. Effects of wildfire on a Sonoran desert plant community. Ecology 63:246-248.

Price, D. L., R. K. Heitschmidt, S. L. Dowhower, and J. R. Frasure. 1985. Rangeland vegetation response following control of brownspine pricklypear (Opuntia phaecantha) with herbicides. Weed Science 33:640-643.

ReYnolds, H. G., AND J. W. Bohning. 1956. Effects of burning on a desert grass-shrub range in southern Arizona. Ecology 37:769-777.

Russell, C. E., and P. Felker. 1987. The prickly-pears (Opuntia spp., Cactacae): a source of human and animal food in semi-arid regions. Economic Botany 41:433-445.

Scifres, C. J., and W. T. Hamilton. 1993. Prescribed burning for brushland management-The south Texas example. College Station: Texas A\&M University Press. $246 p$.

Sickerman, S. L., AND J. K. Wangberg. 1983. Behavioral responses of the cactus bug, Chelinidea vittiger Uhler, to fire damaged host plants. Southwestern Naturalist 8:263-267.

Singh, G. 2003. General review of Opuntias in India. Journal of the Professional Association for Cactus Development 2003:30-46.

[SPSS] Statistical Package for the Social Sciences. 2003. Release 12.0.0. Chicago, IL: SPSS Inc.

TAYLOR, C. A. 2001. Summer fire for the western region of the Edwards Plateau: a case study. Sonora, TX, TAES Technical Report 01-2. 23 p.

Thomas, P. A. 1991. Response of succulents to fire: a review. International Journal of Wildland Fire 1:11-22.

Thomas, P. A., And P. Goodson. 1992. Conservation of succulents in desert grasslands managed by fire. Biological Conservation 60:91-100.

Trollope, W. S. W. 1984. Fire in savanna. In: P. de V. Booysen and N. M. Tainton [EDS.]. Ecological effects of fire in South Africa ecosystems. Ecological Studies 48. Berlin-Heidelberg, Germany: Springer-Verlag. p 149-175.

Van Auken, 0. W. 2000. Shrub invasions of North American semiarid grasslands. Annual Review of Ecology and Systematics 31:197-215.

Vila, M., J. A. Burriel, J. Pino, J. Chamizo, E. Llach, M. Porterias, and M. Vives. 2003. Association between Opuntia species invasion and changes in land-cover in the Mediterranean region. Global Change Biology 9:1234-1239.

WenlGer, D. 1988. Cacti of Texas and neighboring states. Austin: University of Texas Press. $356 \mathrm{p}$.

Wright, H. A., and A. W. Balley. 1982. Fire ecology. New York, NY: WileyInterscience, John Wiley and Sons. $501 \mathrm{p}$.

ZaR, J. H. 1999. Biostatistical analysis. 4th ed. Upper Saddle River, NJ: Prentice Hall. $663 p$. 